\title{
THE REFUSAL AGAINST 1925 TEACHER ORDINANCE IN WEST SUMATRA: ITS CONDITIONS, COURSE, AND AFTERMATH
}

\author{
Muhammad Yuanda Zara, Ph.D.*
}

\begin{abstract}
Worried with the rise of modernist Muslim movement coming from the Middle East, in 1925 Netherlands Indies Government issued and applied Teacher Ordinance (Goeroe Ordonnantie) in several regions in Netherlands Indies. It stipulated, among others, that every Muslim teacher must report himself to district head so that the district head could immediately issue a letter of identification, that Islamic teachers must keep the list of their students and religious subjects given to them, and the situation in which the right of teaching would be canceled, for example if the Islamic teachers provoke their students to condemn the Government. The Ordinance had been successfully applied and the Government planned to extend it to other regions, including West Sumatra. Yet, the majority of Islamic teachers throughout West Sumatra refused the plan. The refusal against 1925 Teacher Ordinance, in the form of mass demonstration and negotiation, influenced almost all of Islamic teachers in West Sumatra and reduced existing social and religious gaps in Minangkabau society due to the same feeling of dissatisfaction. Eventually, the Government canceled the application plan of the Ordinance in West Sumatra, showing the effectiveness of the social movement organized by Islamic teachers in West Sumatra.
\end{abstract}

Keywords: Teacher Ordinance, social movement, Islamic teachers, West Sumatera, Islam and colonialism

\begin{abstract}
Abstrak
Khawatir dengan kebangkitan gerakan Islam modernis yang datang dari Timur Tengah, pada tahun 1925 Pemerintah Kolonial Hindia Belanda mengeluarkan dan menerapkan Goeroe Ordonnantie (Ordonansi Guru) untuk beberapa daerah di Hindia Belanda. Ordonansi ini menegaskan bahwa, antara lain, setiap guru agama Islam harus melaporkan diri pada kepala distrik sehingga kepala distrik bisa mengeluarkan surat identifikasi, bahwa guru agama Islam harus mempunyai daftar murid dan daftar subyek yang diajarkan pada mereka, dan situasi di mana hak mengajar akan dibatalkan, misalnya ketika para guru agama memprovokasi murid mereka untuk melawan Pemerintah. Ordonansi ini berhasil diterapkan dan Pemerintah berencana untuk memperluasnya ke daerah lain, termasuk Sumatera Barat. Namun, mayoritas guru agama di seluruh Sumatera Barat menolak rencana tersebut. Penolakan terhadap Goeroe Ordonnantie tahun 1925, dalam bentuk demonstrasi massa dan negosiasi, mempengaruhi hampir semua guru agama Islam di Sumatera Barat dan mengurangi jarak sosial dan keagamaan yang eksis di tengah masyarakat Minangkabau lantaran adanya perasaan kekecewaan bersama. Akhirnya, Pemerintah membatalkan rencana menerapkan Ordonansi ini di Sumatera Barat, menunjukkan keefektifan gerakan sosial yang dijalankan oleh para guru agama Islam di Sumatera Barat.
\end{abstract}

Kata kunci: Goeroe Ordonnantie, gerakan sosial, guru agama Islam, Sumatera Barat, Islam dan kolonialisme

\section{A. Introduction}

In the early of the $20^{\text {th }}$ century, West Sumatra was one of the most dynamic regions in the Netherlands Indies. People of West Sumatra (Minangkabauese) faced their own natural changes as a result of its internal conflict and competition. Well-known with their strong Islamic belief, Minangkabau Muslim split into several parties, Kaum Muda (Modernist-Progressive) and Kaum Tua (Traditional-Conservative). ${ }^{1}$ On the other hand, another influential group in the society, Kaum Adat (Traditional Leader) also did the best for their own interest.

Outside of Minangkabau society, one primary factor driving Minangkabau society into changes was the Netherlands Indies Government. Since the Government defeated

\footnotetext{
* Staf Pengajar Ilmu Sejarah UNY. myuzara@gmail.com

${ }^{1}$ Murni Djamal, DR. H. Abdul Karim Amrullah: Pengaruhnya dalam Gerakan Pembaruan Islam di Minangkabau pada Awal Abad ke-20 (Jakarta and Leiden: INIS, 2002), pp. 3-10.
} 
Minangkabau's people rebellion in 1837 (the Padri War), the Government set a deep root in Minangkabau society. ${ }^{2}$ In 1840 s, the Government applied forced coffee cultivation. This changed Minangkabau society, especially related to the penetration of money economic. The Government afterwards applied the tax system, but the Minangkabauese refused it, which ended in the bloody 1908 anti-tax rebellion. ${ }^{3}$

Other progress gradually took place in West Sumatra. The introduction of Western education system pulled Minangkabauese children to enroll, which, as a result, set West Sumatra as a region which produced early Indonesian intellectuals and scholars. ${ }^{4}$ Moreover, another group arose and attracted Minangkabauese's attention, namely the communist group. Trying to combine Islamic doctrine with communist viewpoints, West Sumatran communists organized a systematic rebel centered in Silungkang in 1927. The rebellion failed miserably and caused a lot of casualties and banishments. ${ }^{5}$

Surrounded by these social changes, in 1925 the Government released a new regulation dealing with Islamic affairs. ${ }^{6}$ Since Islam was considered as the belief hold by most of the Netherlands Indies population, this new regulation would influence almost all of social life in Indonesian archipelago. Anxious about the rise of modernist Muslim movement coming from the Middle East, especially reformation idea by Muhammad Abduh and Rashid Rheda, the Government issued and applied Teacher Ordinance (Goeroe Ordonnantie), particularly for several certain regions in the Indies (excluding West Sumatra). Previously, a relatively same regulation had been applied since 1905 in Java and Madura, also under the name of Teacher Ordinance. $^{7}$

The 1925 Teacher Ordinance had been successfully applied in some regions in the Indies. Subsequently, the Government tried to extend it to the other regions. One of the targets was West Sumatra. Since West Sumatra was considered as an area which had significant number of Islamic teachers, and as a result, played an important role in the rise of Muslim movement in the Indies, it can be said that control over Islam in West Sumatra was one of the main goals

\footnotetext{
2 To understand the process of Dutch penetration in West Sumatra and how the Minangkabauese responded it, see Christine Dobbin, Islamic Revivalism in a Changing Peasant Economy: Central Sumatra 1784-1847 (London \& Malmo: Curzon Press, 1983).

${ }^{3}$ Ken Young, Islamic Peasant and the State: The 1908 Anti-Tax Rebellion in West Sumatera (Connecticut: Yale University Southeast Asian Studies, 1994).

${ }^{4}$ See Elizabeth Graves, "The Ever-Victorious Buffalo: How the Minangkabau of Indonesia Solved Their 'Colonial Question"”, PhD dissertation at University of Wisconsin, 1970.

5 The complete story about the Silungkang rebellion can be found in Mestika Zed, Pemberontakan Komunis Silungkang 1927: Studi Gerakan Sosial di Sumatera Barat (Yogyakarta: Syarikat, 2004) and Harry J. Benda and Ruth T. McVey, The Communist Uprisings of 1926-1927 in Indonesia: Key Documents (New York: Modern Indonesia Project Southeast Asia Program Departement of Far Eastern Studies Cornell University, 1960).

${ }^{6}$ Taufik Abdullah, Schools and Politics: The Kaum Muda Movement in West Sumatra (1927-1933) (New York: Cornell Modern Indonesia Project, 1971), pp. 112-113.

7 The difference is in the words redaction. The 1905 Ordinance stated that every Islamic teacher who will teach Islamic doctrine must enroll and get permission to and from the Government (Patih, Regent, etc). The 1925 Ordinance was softer than the previous one, because it was not necessary for an Islamic teacher to get permission; all he had to do is only to report himself to the Government. See Staasblad van Nederlandsch-Indie 1925 No. 219.
} 
behind this regulation. Although this regulation was arguably softer than the previous one, the Government effort in applying this regulation in West Sumatra faced major obstacles. Most of the Islamic leaders (ulama) thought that this ordinance would limit their freedom in spreading Islamic teaching. ${ }^{8}$

Given the background mentioned above, this paper seeks to understand how the plan to apply Teacher Ordinance was responded by the Islamic teachers in West Sumatra, especially by focusing on such aspects as the growth of modern Muslim movement in West Sumatra and the position of Islamic schools and teachers in that process, the reasons behind Government plan to apply the ordinance, and in what ways and forms the local Islamic teachers reacted to the plan.

Some works have explored several parts of the ordinance. Yet, such mentioning was very limited, and was usually put as one of Islamic teachers' anti-Dutch moves, without further details, for instance Taufik Abdullah's dissertation ${ }^{9}$ and Deliar Noer's work on the modern Muslim movement in Indonesia in the first half of $20^{\text {th }}$ century. ${ }^{10}$ HAMKA, in his book about the biography of his father, Ajahku, shows personal thought and actions of his father, Haji Abdul Karim Amrullah, or Haji Rasul, against that ordinance. ${ }^{11}$ Murni Djamal also confirms Haji Rasul's role in the movement in his biography of Haji Rasul. ${ }^{12}$ Another relevant work is by Burhanuddin Daya, which deals with the growth of Sumatra Thawalib school, a modern Islamic school which was built around $1918 .{ }^{13}$ The application of the Ordinance is a direct attack to this institution, and it is then understandable that the most powerful refusal against the Ordinance came from the Islamic teachers in this school.

This work is a historical study of a social movement in West Sumatra, by paying attention to a dynamic process among the social group which was mobilized by an ideological aim. ${ }^{14}$ The refusal against the 1925 Teacher Ordinance did not suddenly occur, and there must be some causes behind it and it is very likely that previous factors accumulated and finally erupted. I use several relevant primary sources, namely Staatsbladen, Verbalen, and Mailrapporten. ${ }^{15}$ These primary sources are important, especially in understanding reasons and considerations

\footnotetext{
${ }^{8}$ The others even felt that they were no longer played as ruler of their own land. In the peak of the dissatisfaction, some ulama argued that this regulation was a direct attack to Islam, and for the consequence, the ulama must declare a holy war (perang sabil). See Taufik Abdullah, Schools and Politics, pp. 112-113.

${ }^{9}$ Taufik Abdullah, Schools and Politics.

${ }^{10}$ Deliar Noer, The Modernist Muslim Movement in Indonesia 1900-1942 (Kuala Lumpur: Oxford University Press, 1973).

${ }^{11}$ HAMKA, Ajahku: Riwajat Hidup Dr. H. Abd. Karim Amrullah dan Perdjuangan Kaum Agama di Sumatera (Jakarta: Djajanurni, 1967).

${ }^{12}$ Murni Djamal, DR. H. Abdul Karim Amrullah: Pengaruhnya dalam Gerakan Pembaruan Islam di Minangkabau pada Awal Abad ke-20 (Jakarta and Leiden: INIS, 2002).

13 Burhanuddin Daya, Gerakan Pembaharuan Pemikiran Islam: Kasus Sumatera Thawalib (Yogyakarta: Tiara Wacana, 1990.

${ }^{14}$ Sartono Kartodirdjo, Pendekatan Ilmu Sosial dalam Metodologi Sejarah (Jakarta: Gramedia, 1992), p. 51.

15 Several importants archives are Staatsblad van Nederlandsch-Indie 1915 No 550 and Staatsblad van Nederlandsch-Indie 1925 No. 219 (both are about the Goeroe Ordonnantie),
} 
made by the Government. Others are taken from articles, books, dan dissertations in English, Bahasa Indonesia, and Dutch.

\section{B. Colonial Government Policy on Indonesian Muslim}

I will first focus on the Netherlands Indies Government's policy toward Indonesian Muslim, which was strongly based on its aim to defend its position as colonial power. Since the late of $19^{\text {th }}$ century, Islamic policy of the Government was strongly influenced by the advice of Snouck Hurgronje, a famous expert in Islamic studies. The coming of Snouck Hurgronje in 1889 to the Indies set a clear position of the Government in seeing Islamic affairs. He underlined that the Government must deal with Islamic affairs, instead of avoiding it. He introduced a new way in treating Islamic affairs, which known as Islam Politiek. The main idea behind this policy was the separation of Islam into three elements, namely ritual, political and social aspect. Since it was separated, the handling must be separated as well. Meanwhile, in social aspect, Snouck proposed the association policy, related to the way of uniting the colony and the ruling country through culture, including via Western-based education for a part of local population. ${ }^{16}$

A backbone of the so-called ethical policy of the colonial government was education. The Government had been attempting to provide schools for the member of Indonesian noble families. It was mainly addressed to prepare them to join into colonial bureaucracy. In Holland Inlandsche School (HIS), for instance, Indonesian students were taught Dutch since this language was necessary for certain positions in colonial bureaucracy. On the other hand, it was also believed that Western education could be directed to undermine Indonesian Islam, because Islam was considered as frozen and blockading the progress. ${ }^{17}$ Furthermore, that attempt was strengthened by the Government decision to let Christian schools to be used to propagate Christianity to Muslim students. ${ }^{18}$ Christian schools mostly obliged their students, including Muslim students, to learn Bible. Those situations sparked Muslims' opposition, especially shown by the spreading of anti-Government propaganda in Islamic schools.

\section{The 1905 Teacher Ordinance}

In particular cases, the Dutch policy toward Indonesian Muslim was strongly based on both social and political considerations. One of it can be seen from the application of the 1905 Teacher Ordinance. In order to accelerate the cultural association, the Government expanded the Government schools by aiding Western-oriented (including Christian) schools. At the same time, the Government was also facing the rapid growth of Muslim mass movement which threatened

\footnotetext{
${ }^{16}$ Aqib Suminto, Politik Islam Hindia Belanda, Het Kantoor voor Inlandsche Zaken (Jakarta: LP3ES, 1985), p. 12. See also Deliar Noer, The Modernist Muslim Movement in Indonesia 1900-1942 (Kuala Lumpur: Oxford University Press, 1973), pp. 165-168.

${ }^{17}$ Aqib Suminto, Politik Islam Hindia Belanda, pp. 48-49.

${ }^{18}$ Aqib Suminto, Politik Islam Hindia Belanda, p. 51.
} 
the existence of colonial Government. In 1888, an anti-Government movement erupted in Cilegon (Banten), and as a result, the Government hunted the Mecca returnees (haji) and Islamic teachers who were considered as the leaders of the movement. ${ }^{19}$ Responding to this, in 1904 Snouck Hurgronje advised the Government to supervise Islamic teachers, encompassing special permission from regent and a list of teachers and students. ${ }^{20} \mathrm{He}$ believed that the Islamic teachers had already moved from their religious world to be more active in social and political life.

The Government, which was extremely concerned with the dangerous effects of Islamic teachers, took Snouck's advice into consideration. A specific regulation was needed to avoid Islamic education from spreading Pan-Islam and holy war idea. ${ }^{21} \mathrm{~A}$ year after, the Government issued the 1905 Teacher Ordinance. ${ }^{22}$ This ordinance stated that every Islamic teacher must have a written permission from Regent, Patih or district head before teaching (article 1). The school subjects were also included in that permission letter. It was also necessary for every Islamic teacher to write a list of his students and report it to the district head periodically, including if he wanted to accept students coming outside of his region. This ordinance was only applied in Java and Madura, except Yogyakarta and Surakarta.

The regents were the backbone of this ordinance. To guide them, the Central Government published a guidebook entitled Handleiding Ten Dienste van de Inlandsche Bestuursambtenaren op Java en Madoera No. 37/O. E. Mohammedaansch-Inlandsche Zaken. This book contains the list of what the regent must do regarding to Islamic affairs in their regency. ${ }^{23}$ However, some regents, who had authority to supervise the Islamic teachers, exaggerated their report in order to gratify the Government. ${ }^{24}$

As mentioned earlier, instead of protesting against this ordinance, most of Muslim in Java only showed their dissatisfaction. The reason behind this can be traced from "the low level of consciousness concerning the effect of the decree as well as the ignorance of leaders about how to organize themselves at that time against the Government". ${ }^{25}$ As explained by Deliar Noer, the idea of takdir (fatalism) perhaps played important role here. ${ }^{26}$ This situation had

19 Muhammad Hisyam, "Caught Between Three Fires: The Javanese Pangulu under the Dutch Colonial Administration 1882-1942", PhD disssertation at Leiden University, 2001, p. 90. To understand the 1888 antiGovernment revolt in Banten, see Sartono Kartodirdjo, The Peasant' Revolt of Banten in 1888: Its Conditions, Course and Sequel: A Case Study of Social Movements in Indonesia ('S-Gravenhage: Martinus Nijhoff, 1966).

${ }^{20}$ Aqib Suminto, Politik Islam Hindia Belanda, pp. 51-52.

${ }^{21}$ I. J. Brugmans, Geschiedenis van het Onderwijs in Nederlandsch-Indie (Groningen and Batavia: J. B. Wolters' Uitgevers-Maatschappij N.V., 1938), p. 8.

${ }^{22}$ Staatsblad van Nederlandsch-Indie 1905 No. 550..

23 See Handleiding Ten Dienste van de Inlandsche Bestuursambtenaren op Java en Madoera No. 37/O. E. Mohammedaansch-Inlandsche Zaken (Batavia: het Departement van Binnenlandsch-Bestuur, 1920), pp. 4-6.

${ }^{24}$ For instance, in a periodic report written by Resident of Yogyakarta since the late of $19^{\text {th }}$ century, it was mentioned that there was a famous Islamic teacher named K.H. Imam Tafsir Krapyak in that region. But, when another officer conducted a crosscheck, it was known that Tafsir Krapyak only taught about 20 students. The problem is then, according to the Government's viewpoint, an Islamic teacher who had only 20 students can not be said as "famous". See Aqib Suminto, Politik Islam Hindia Belanda, pp. 53-54

${ }^{25}$ Deliar Noer, The Modernist Muslim Movement in Indonesia, pp. 175-176.

${ }^{26}$ Deliar Noer, The Modernist Muslim Movement, p. 176. 
changed when a strong, popular-based Islamic party named Sarekat Islam was established in 1911 and gradually attempted to persuade Javanese Muslim to refuse that ordinance.

The Government gathered reports of the Islamic teachers periodically, but most of them were not convincing, especially because the contents of the reports were sometimes overstated. The Central Government had stricter category in considering an Islamic teacher as "influential" or not than the local chiefs' own category. Since the reports were out of expectation, the existence of this ordinance was questionable. The fact that this ordinance failed due to technical problems and the deviation of its aim showed that the reason behind this ordinance was fear instead of necessity. In addition, this ordinance not only proved that the Government had broken its neutrality in religious affairs but also "triggered the hatred of Muslim society to the Government". ${ }^{27}$ The Government afterwards decided to rethink the existence of this ordinance. Finally, in 1920s, the Government withdrew the ordinance.

\section{The 1925 Teacher Ordinance and Its Extension Plan to West Sumatra}

Instead of ceasing the efforts to deal with the Islamic teachers, the Government continued to find a more effective way. Realizing that complex procedure only created administrative problems and that a harsh regulation would only create sharp opposition, in 1925 the Government issued a new Teacher Ordinance. This new regulation was comparatively milder than the previous one. It stipulated that every Muslim teacher must report himself (asking permission is no longer necessary) to the district head so that the district head could immediately issue a letter of identification (article 1). ${ }^{28}$ Article 1 also mentioned that this ordinance was applied in Java, Madura, and outer islands (not specified). Article 2 stipulated that Islamic teachers must keep the list of their students and religious subjects delivered to them. The district head was responsible to check whether that record is true or not. This ordinance also mentioned the inspection mechanism, including the inspector attending the class (article 3 and 4). Article 5 stipulated the situation in which the right of teaching would be canceled, for example if the Islamic teachers provoke their students to condemn the Government. Information related to the violation of this ordinance was mentioned in article 6, 7 and 8. Article 9 explained about the requirements of Islamic teaching outside of Java while article 10 emphasized that this ordinance was not applicable in self-governing regions (zelfbesturende landschappen). The last two articles (11 and 12) related to the name of the ordinance and the application date. ${ }^{29}$

Although it was softer than the previous one, this new regulation directly provoked refusal from Muslim community. For them, the problem was not asking permission or reporting oneself, but that the supervision over Islamic teachers was a hindrance to the spread of Islam. In its congress in 1926, a Muslim organization named Al-Islam rejected the ordinance by saying

\footnotetext{
${ }^{27}$ Harry J. Benda, Bulan Sabit dan Matahari Terbit, pp. 101.

${ }^{28}$ Staatsblad van Nederlandsch-Indie 1925 No. 219.

${ }^{29}$ Staatsblad van Nederlandsch-Indie 1925 No. 219.
} 
that ordinance as a heavy burden on Muslim. Another Muslim organization, the modernist Muhammadiyah, since 1926 onwards fiercely asked the Government to revoke the ordinance. ${ }^{30}$

Meanwhile, the Government had a plan to broaden again the scope of the ordinance. From the Government's viewpoint, this ordinance could be applied in outer islands by considering "particular local conditions". 31 Therefore, the timing and the reasons for applying that ordinance in West Sumatra, a region which was called as "a rendezvous for Islam in Sumatra" by Verkerk Pistorius, ${ }^{32}$ were appropriate. For the Government, the effort to control Islamic education in that region was indispensable because the Government had been facing troubles conducted by Islamic institutions there. ${ }^{33}$ Until 1920s, several rebellions against the Government occurred in this region, mostly led by the Islamic teachers (especially Islamic mystical brotherhood or tarekat teachers), ${ }^{34}$ including the anti-tax revolt in Kamang in 1908, the anti-Government rebellion in holy grave of Ulakan on May 20, 1909, and the attack of Assistant Resident's abode in Padang Panjang in December 1915, ${ }^{35}$ respectively. In January 1927, there was also a bloody communist rebellion in Silungkang, which was organized by Islamic teachers and students, who many of them were affiliated to Thawalib School.

Moreover, since the 1920s onwards the progressive Muslim movement gradually arose as one of the most influential streams of power in West Sumatra, taking over the role of tarekat teachers. Initially, the Government had no suspicion towards them, because their initial aim was to purify Islam, especially from the influence of mystical aspects and some Minangkabau traditional behaviors which they considered as forbidden in Islam. To certain extent, the Government believed that the reformist group "neither anti-Government nor interested in political life". ${ }^{36}$ But, since 1920s, this group took over the role of traditional educational system (surau) and the role of tarekat teachers, especially through schools they had been building in all over West Sumatra. Some of them even acted further; they raised a question, why an infidel

\footnotetext{
${ }^{30}$ Alfian, Muhammadiyah: The Political Behavior of a Muslim Modernist Organization under Dutch Colonialism (Yogyakarta: Gadjah Mada University Press, 1989), pp. 213-214.

31 Taufik Abdullah, Schools and Politics, p. 113.

${ }^{32}$ C. Snouck Hurgronje, Tulisan-tulisan tentang Islam di Hindia Belanda (jajaran pertama): Kumpulan Karangan Snouck Hurgronje VII (Jakarta: INIS, 1993), p. 28.

${ }^{33}$ Burhanuddin Daya, Gerakan Pembaharuan Pemikiran Islam, pp. 260-261. See also Azyumardi Azra, Surau: Pendidikan Islam Tradisional dalam Transisi dan Modernisasi (Jakarta: Logos Wacana Ilmu, 2003), pp. 130-131.

${ }^{34}$ Burhanuddin Daya, Gerakan Pembaharuan Pemikiran Islam, pp. 260-261

35 This attack killed assistant resident's guards. The examination concerning this case concluded that the attackers were provoked by the agitation of the Islamic teachers. These teachers were considered using "bekrompen godsdienst onderwijs" (narrow-minded religious education) to persuade people to fight against the colonial Government. Because of that, central government was hoped to supervise these Islamic teachers and their teachings. See Nota van den Assistant-Resident van Batipoeh en Pariaman betreffende het gebeurde te Padang Pandjang in den nacht van 21 op 22 December 1915, Verbaal De Ministerie van Kolonien 15 Juni 1916 No. 41.

${ }^{36}$ Azyumardi Azra, Surau, p. 131. See also Taufik Abdullah, Schools and Politics, p. 52.
} 
power could have authority over Muslim society. ${ }^{37}$ Their actions attracted Minangkabauese and, at the same time, made them as a new threat for the Government.

The Government acted very carefully to deal with the Minangkabauese's Islamic teachers. First thing to do before applying the ordinance was to understand the community in which such regulation would be implemented. Senior adviser in the Office for Native Affairs, E. Gobée, attempted to find out the possibilities of declaring the ordinance in West Sumatra by visiting the area in February 1928. Gobée thought that this ordinance had a chance to produce hazardous effect to the Government. Instead of applying the ordinance as soon as possible, he advised the Government to firstly conduct more investigation on the current situation in West Sumatra. The Governor-General agreed, and in June ordered the Resident of the West Coast of Sumatra to inquiry about the "possibilities and advantages" of applying the ordinance in this region. ${ }^{38}$ The person executing this task was the representative of the Office for Native Affairs in Sumatra, L. de Vries.

\section{E. Response of West Sumatran Islamic Teachers}

The distribution of information regarding the Government's Islamic policy among Indonesian Muslims was strongly influenced by the networks of Indonesian Muslims which crossing land and sea. This is especially the case in the spread of the information related to the application plan of the 1925 Teacher Ordinance in West Sumatra. In 1928, Muhammadiyah held a congress in Yogyakarta, Central Java. ${ }^{39}$ One of the attendants was a Minangkabau Islamic teacher named Sutan Mansyur. This congress was not only an organizational consolidation, but also a place to discuss current issues in Netherlands Indies, in which the 1925 Teacher Ordinance was one of them. Muhammadiyah officially rejected that ordinance. After attending this congress, Sutan Mansyur informed Muhammadiyah's refusal to his father-in-law, who was also one of the most influential ulama in West Sumatra, Haji Rasul. ${ }^{40}$ Sutan Mansyur also warned that this ordinance would blockade the freedom of spreading of Islamic teaching, the learning of Koran, etc.

Considering that the ordinance would be a threat for him, his school, and for Islamic teachers in West Sumatra, Haji Rasul took action. He invited twenty Kaum Muda ulama and their former students into a secret meeting in Bukittinggi (or Fort de Kock, about $120 \mathrm{~km}$ northern Padang) on June 14, 1928. ${ }^{41}$ They discussed the ordinance, especially its content and consequences. One participant named Jamaan Sidi Sutan read that ordinance in Ducth and

\footnotetext{
${ }^{37}$ HAMKA, Ajahku: Riwajat Hidup Dr. H. Abd. Karim Amrullah dan Perdjuangan Kaum Agama di Sumatera (Jakarta: Djajamurni, 1967) pp. 262-263 and William R. Roff, "Indonesian and Malay Students in Cairo in the 1920's" in INDONESIA Vol. 9, April 1970, p. 3.

38 Taufik Abdullah, Schools and Politics, p. 118.

${ }^{39}$ HAMKA, Ajahku: Riwajat Hidup Dr. H. Abd. Karim Amrullah dan Perdjuangan Kaum Agama di Sumatera (Jakarta: Djajanurni, 1967), p. 150.

40 Taufik Abdullah, Schools and Politics, p. 113.

${ }^{41}$ Taufik Abdullah, Schools and Politics, p. 113.
} 
afterwards translated it into Malay. Almost all of the participants showed their disagreement to that ordinance. Haji Rasul himself said that, "Perhaps the Dutch consider that we are so stupid!" ${ }^{42}$ According to Schrieke, the ulama's objection arose because "they felt very much injured since their age-old rights were ignored."43

Believing that the ordinance would deprive their role as Islamic teachers, they chose to refuse it. In order to strengthen their refusal action, they also insisted that the action of rejection could only succeed by a mass refusal. In order to do that, a general meeting was planned to be held on August 18, 1928. ${ }^{44}$ The ulama afterwards would take a role as propagandist while younger Islamic teachers were ordered to make a contact to other Islamic teachers in whole West Sumatra and persuade them to join into the refusal action. These younger educators were financed by the ulama and also were sworn in. If necessary, they were allowed to be in disguise. Haji Rasul's son, Abdul Malik Karim Amrullah, was disguised as an ordinary trader and went to south part of West Sumatra.

Bukittinggi was chosen as a city where that public meeting will be held, considering certain advantageous conditions there. ${ }^{45}$ As one of three main centers of Islamic reformism in West Sumatra (besides Padang and Padang Panjang), Bukittinggi furnished more religious atmosphere than any other cities, therefore could fuel audience's psychological state. This city is also situated in the middle of West Sumatra so that it was easy to be accessed. Politically speaking, Bukittinggi was relatively "clean" from the 1927 communist rebellion.

In the meantime, the representative of the Office for Native Affairs in Sumatra, De Vries, started to convince Islamic teachers in West Sumatra to accept the Ordinance. ${ }^{46}$ Later, in his secret report to the Resident of West Sumatra he wrote that after several approaches he gained an initial support from religious teachers (and also village chiefs) in Lubuk Sikaping, Sawah Lunto, Sijunjung, Muara Labuh, Balai Selasa, and Kerinci. ${ }^{47}$ Nevertheless, all of these areas were not the centers of the Kaum Muda's ulama, or on the other words, not regions where a lot of modern Islamic schools were built. So, it is likely that this the reason why De Vries could get initial agreement from the Islamic teachers. Several center areas of modern Islamic schools, including Fort van der Capellen, Payakumbuh, Suliki, Singkarak, Solok, Alahan Panjang, and Painan remained difficult to be persuaded.

In the meantime, from the information he had gathered, De Vries knew that Haji Rasul was the most prominent ulama in leading people's grievances concerning that ordinance.

\footnotetext{
${ }^{42}$ HAMKA, Ajahku, p. 151.

43 B. Schrieke, Indonesian Sociological Studies: Selected Writings of B. Schrieke Part One (The Hague and Bandung: W. van Hoeve Ltd, 1955), p. 159.

${ }^{44}$ B. Schrieke, Indonesian Sociological Studies, p. 159.

${ }^{45}$ Zulqayyim, Boekittinggi Tempo Doeloe (Padang: Andalas University Press, 2006), pp. 114-115.

46 Zulqayyim, Boekittinggi, p. 113.

${ }^{47}$ Letter from De Ambtenaar voor Inlandsche Zaken De Vries to the Resident of West Sumatra No. 41 (Geheim), Onderwerp-Goeroe-Ordonnantie, Fort de Kock, dated September 5, 1928, in Mailrapport 966x/28, p. 5.
} 
Therefore, De Vries visited Haji Rasul and attempted to persuade him. ${ }^{48}$ In front of Haji Rasul, De Vries firstly paid a compliment to him, by saying that he had already read Schrieke's and Hazeu's books which discussing about Haji Rasul. Afterwards he attempted to convince Haji Rasul that the ordinance was not a danger to Islamic teachers. But, Haji Rasul tactfully declined it by stating that he would accept that ordinance only if all of Islamic teachers in West Sumatra accept it. Since De Vries knew that this "requirement" could not be fulfilled, he understood that his mission had just failed.

Although de Vries had no success in approaching the Kaum Muda, he succeeded in getting support from a part of Kaum Tua. Haji Abdullah Ahmad, who previously was considered as reformist but later, because of his affinity with the Government, was considered as Kaum Tua, declared his support to the Ordinance. Besides, there were also other influential ulama who proclaimed their support. This support proved the efficacy of the Government approach in gaining support from certain ulama, especially from the ulama who get benefit from their relationship to the Government, including financial aid to their Islamic schools.

\section{F. Mobilization, Demonstration, and Diplomacy}

The network of Islamic schools and the active propagandists were effective in gaining mass support to refuse the Ordinance. The success of that mobilization effort was shown in a big mass meeting held on August 18, 1928, in Bukittinggi. Under the name of The Conference of Ulama in Minangkabau, approximately 800 Islamic teachers from whole West Sumatra attended it. $^{49}$ By representing 115 religious and local organizations, they attempted to show that the Ordinance was a major challenge for them. The Government paid a lot of attention as well. De Vries and other high Dutch officials attended it.

Several influential Kaum Tua ulama, who supported the Ordinance, joined the conference as well. ${ }^{50}$ Among them were Syekh Khatib Ali, Syekh Jamil Jaho and Syekh Arrasuli. ${ }^{51}$ Other Kaum Tua ulama, Chatib Maharaja, even delivered a speech to audience. He proposed the audience to temporarily accept the Ordinance. But, he could not continue his persuasion because the audience were irritated and yelled at him. In front of the Dutch officers, Kaum Muda demonstrated their opposition, not only for the kafir (infidel) government, but for Muslims who supported kafir government as well.

The most influential speech in that conference was delivered by Haji Rasul. ${ }^{52}$ He spoke very enthusiastically, posing the perilous possibility of the Ordinance and quoting Koran to explain the bad effect of the disunity of the ulama. Started with Arabic, he continued his speech

\footnotetext{
${ }^{48}$ HAMKA, Ajahku, p. 152. HAMKA also wrote, De Vries “menanamkan racun” (planted poison) to Haji Rasul by saying Abdullah Ahmad, one of the prominent ulama in West Sumatra, "had agreed" that ordinance.

49 Taufik Abdullah, Schools and Politics, p. 114.

${ }^{50}$ Taufik Abdullah, Schools and Politics, pp. 114-115.

${ }^{51}$ HAMKA, Ajahku, p. 152.

52 Taufik Abdullah, Schools and Politics, pp. 114-115.
} 
in Malay. Through his speech, Haji Rasul successfully articulated people's grievances in front of the Government delegates. The Conference then accepted a decree which refused the Ordinance. ${ }^{53}$ The main contents of the Conference's resolution were 1) all Muslim must obey Islamic instructions, 2) the Teacher Ordinance could destroy the relationship between the government and West Sumatran Muslim, 3) the Ordinance could blockade Muslim's freedom, and 4) it was necessary to send an envoy to Batavia in order to request the Central Government to withdraw the plan to apply the 1925 Teacher Ordinance in West Sumatra. ${ }^{54}$

Haji Abdul Majid and Datuk Singo Mangkuto were elected as the delegations who will deliver that resolution. The message would not only be sent to the Governor-General A.C.D. De Graeff, but also to Volksraad, the Office for Native Affairs, and Tweede Kamer in Den Haag. ${ }^{55}$ Before going to Batavia, Datuk Singo Mangkuto, a prominent student of Haji Rasul, wrote a letter to the Governor-General, displaying his objection to the Ordinance. ${ }^{56} \mathrm{He}$ insisted that Minangkabau people of West Sumatra were irritated by the government policy through Teacher Ordinance. This pain would lead Minangkabauese to withdraw their respect from the Government.

He reminded previous bloody responses of the Minangkabauese to various decisions taken by the Government, such as anti-tax rebellion in 1908 and communist revolt in 1927. By using these two examples, he attempted to show that every burden put on top of Minangkabause's shoulders would result a strong opposition and, if they can not stand any longer, would end up in a more fierce resistance. Moreover, he also underlined that for a hundred years West Sumatran Muslim had lost their freedom in their own homeland. The Government's policies in that region worsened their misery. Singo Mangkuto also viewed the Teacher Ordinance as an obstacle for every Muslim in carrying out their religious duties towards God. Once it happens, they believe that it was a disobedience to God.

Besides Singo Mangkuto, the committee of the Conference of Ulama in Minangkabau also sent a letter of objection to the Governor-General, Volksraad, Adviser for Native Affairs, and Tweede Kamer. ${ }^{57}$ Initially, this letter explained the public meeting the Minangkabau ulama held in Bukittinggi. Then it underlined the reasons why ulama in Minangkabau considered that the Ordinance "beloem patoet" (was not appropriate yet) to be applied in West Sumatra. ${ }^{58}$

In addition to diplomatic efforts, the refusal action was also helped by the newspapers coverage on it, not only in Sumatra but also in Batavia. It marked the increasing role of ulama as an influential pressure group and the importance of that event to the people outside of West

\footnotetext{
${ }^{53}$ Taufik Abdullah, Schools and Politics, p. 115.

${ }^{54}$ Taufik Abdullah, Schools and Politics, p. 115.

${ }_{55}^{55}$ Murni Djamal, DR. H. Abdul Karim Amrullah, p. 112.

${ }^{56}$ Letter from Hassannoeddin gelar Datoek Singo Mangkoeto to the Governor-General of the Netherlands Indies, Fort de Kock (Bukittinggi), dated August 19, 1928, in Mailrapport 1001x/28.

${ }^{57}$ Letter from on the behalf of Permoesjawaratan Oelama2 Minangkabau to the Governor General of Netherlands Indies, Tweede Kamer, Volksraad, and Adviseur voor Inlandsche Zaken, Fort de Kock, dated August 19, 1928, in Mailrapport 1001x/28.

${ }^{58}$ Letter from on the behalf of Permoesjawaratan Oelama2 Minangkabau.
} 
Sumatra. A writer named Sjamsoe Walkamar wrote in Oetoesan Sumatra, published in Medan (East Sumatra), concentrating on the possibility of bad effect of that ordinance and reminding readers with religious wars in Europe. ${ }^{59}$ In the meantime, Fadjar Asia, published in Batavia, also issued an article concerning it. The writer even considered the condition in West Sumatra was strongly colored by a situation of "a small scale holy war". 60

\section{G. Government Response}

The Office for Native Affairs was the Central Government's backbone behind the creation and application of the 1925 Teacher Ordinance. Due to the rejection against the plan of the application of this ordinance in West Sumatra, the officers of this office had two viewpoints. E. Gobée was still assured that this Ordinance was necessary. In contrast, Ch. O. van der Plas, also adviser in the Office, insisted that the Ordinance should not be applied. ${ }^{61}$ Other suggestion came from Resident of West Sumatra, G.F.E. Gongrijp, and Assistant Resident Groeneveld. As the persons on the spot, they strongly realized how fierce the opposition of the Islamic teachers in West Sumatra was. Therefore, they recommended Governor-General to withdraw the implementation plan of the 1925 Teacher Ordinance in West Sumatra. ${ }^{62}$

The Government took such advices into consideration before deciding the future of this Ordinance. The decision came in October 1928, when the Government finally agreed to Van der Plas's viewpoint. Governor-General De Graeff received two Minangkabau delegates in Batavia. ${ }^{63}$ In that meeting De Graeff explained his opinion regarding that Ordinance. Officially, the decision of the Governor-General was: "The Government has not made a decision and it is also in no hurry to decide whether or not the Goeroe Ordinance should be introduced on the West Coast of Sumatra." 64

To avoid any further controversy, Governor-General also mentioned that his command to De Vries was not to apply the Ordinance in West Sumatra, but merely to find out the opinions of the Minangkabau people. On the other hand, Minangkabau ulama considered this decision as their victory. To show the result of their successful effort, they held a public meeting on

\footnotetext{
${ }^{59}$ Oetoesan Sumatra, van 28 Augustus t/m 15 September 1928, nrs. 102 t/m 111, in Overzicht van de Inlandsche en Maleisisch-Chineesche pers/Bureau voor de Volkslectuur en Aanverwante Aangelegenheden. Afd. Pers Overzicht van de Inlandsche pers (Weltevreden: Bureau voor de Volkslectuur en Aanverwante Aangelegenheden. Afd. Pers, 1928).

${ }^{60}$ Fadjar Asia, van 20 t/m 29 September 1928 nrs. 217/225, Overzicht van de Inlandsche en Maleisisch-Chineesche pers, p. 15.

61 Taufik Abdullah, p. 119. Later, in 1931, he sent a report to the Governor-General of the Netherlands Indies, emphasizing this Ordinance as waardeloos (worthless)

62 Zulqayyim, Boekittinggi, p. 117.

${ }^{63}$ Alfian, Muhammadiyah, p. 274.

${ }^{64}$ Quoted from Taufik Abdullah, Schools and Politics, p. 119.
} 
November 3, 1928, in Bukittinggi, attended by around 1500 people. ${ }^{65}$ The Minangkabau delegates proudly spoke about the result of their meeting with the governor-general. ${ }^{66}$

\section{H. The Aftermath}

The successful attempt of West Sumatran Islamic teachers in refusing the application plan of the 1925 Teacher Ordinance increased their self-confidence. Minangkabau people had just been wounded by the failure of the 1927 communist rebellion, and this successful antiGoeroe Ordonnantie effort had lifted their pressed feeling. ${ }^{67}$ Minangkabau ulama believed that the decision of cancellation from Governor-General was the outcome of their strong effort to fight against the heavy policy imposed by the Government and the effect of their unity as well. ${ }^{68}$ Ulama were then considered as the most forefront leaders in expressing Minangkabauses's objection.

In addition, through the refusal action the Kaum Muda ulama even developed a new "political myth" in Minangkabau society, "a myth in which the Minangkabau people had scored a great victory" ${ }^{69}$ This myth was valuable, especially in aiding the psychological effect to the reformist Muslim movement in Minangkabau, which afterwards was shown by their various numbers of actions.

This achievement not only lifted ulama's position in the eyes of the Minangkabau people, but also in the eyes of the ulama's competitor, the adat supporters. For adat supporters, the success of the Islamic teachers marked their "serious political setback", in which their role in Minangkabau society fell. ${ }^{70}$ They were the right hand of the Government and the Government had already succeeded in gaining their support to impose the Ordinance. But the ulama's efficacious motions brought them into fatal political loss. Minangkabau people believed that the local authorities no longer had influence to express public's objections.

The Government considered that such anti-ordinance action as "the peak of political movement of West Sumatran Kaum Muda under the Sumatra Thawalib's teachers after the failure of that school in attacking the Government through communist supporters in it". ${ }^{71}$ That is why the Government increased their supervision, even though without a special regulation. One important man that was strongly supervised overtly and covertly is Haji Rasul. Haji Rasul fully realized that his popularity "drastically increased" in Minangkabau Muslim after the success against the Teacher Ordinance. ${ }^{72}$ Because of his continuous efforts to attack the Government, Resident of West Sumatra, Gongrijp, paid more attention on him. Haji Rasul was then secretly

\footnotetext{
${ }^{65}$ Deliar Noer, The Modernist Muslim Movement in Indonesia, p. 179.

${ }^{66}$ Burhanuddin Daya, Gerakan Pembaharuan Pemikiran Islam, p. 264.

${ }^{67}$ HAMKA, Ajahku, Ibid, p. 153.

${ }^{68}$ Deliar Noer, The Modernist Muslim Movement in Indonesia, p. 179.

${ }^{69}$ Taufik Abdullah, Schools and Politics, p. 119.

${ }^{70}$ Murni Djamal, DR. H. Abdul Karim Amrullah, p. 113,

${ }^{71}$ Burhanuddin Daya, Gerakan Pembaharuan Pemikiran Islam, p. 264.

${ }^{72}$ Murni Djamal, DR. H. Abdul Karim Amrullah, p. 114.
} 
followed by Dutch agent wherever he went. His speeches were also regularly reported to the Government.

Moreover, while the Government let Islamic teachers in West Sumatra to be free from the 1925 Teacher Ordinance, several other parts of Netherlands Indies were still carrying out that ordinance, at least until the beginning of 1930s. But, the effectiveness of that Ordinance was still uncertain. The rejection of Muslim community was not only the reason behind it. Similar to the previous ordinance, this ordinance also faced a grave administrative problem. In 1934 Van der Plas argued that the teacher list was not useful at all in supervising Islamic education, emphasizing the unimpressive report his office received. Since the report was very ambiguous, he viewed that ordinance as the waste of paper. Therefore he suggested, in order to simplify and to make a more effective work, the Government should withdraw that ordinance. ${ }^{73}$

\section{Conclusion}

The 1925 Teacher Ordinance, which had already been applied in some regions in Java, Madura, and Sumatra, required every Islamic teacher to report himself to the local chief before teaching. A number of Islamic teachers in West Sumatra refused it. Instead of using an armed fighting like previous religious-based protests, they conducted different ways in showing their grievances. The widespread network of modern Islamic schools in West Sumatra was very important in spreading the refusal idea to as many Islamic teachers as possible. Moreover, they made use of public meeting to show their influence among West Sumatra population. They also used print media to reach as many support as possible. In addition, they believed the power of diplomatic struggle, seen from their objection letter to the governor-general. Last but not least, the "real killer" of this refusal action came from someone who could lead public's grievances, and it was obviously seen from a very influential leader in this refusal action, Haji Rasul, who was considered as "the father of modernist Muslim movement in West Sumatra" as well.

The fierce oppositions forced the Government to cancel the plan to implement the ordinance in West Sumatra. Later, this ordinance was even discontinued in other parts of Netherlands Indies. Moreover, in the beginning of 1930s, the Government faced a number of economic difficulties as an effect of global financial crisis. The Islamic teachers were also no longer a threat to the Government because national-based political parties had been growing as new influential groups.

The success of the refusal action transformed the position of three authorities in West Sumatra, namely adat leaders, the Government, and the ulama. The adat leader's influence diminished while the Government's role was becoming less strong. The ulama considered themselves as the winner. This refusal action was regarded as the first time ulama could defeat the infidel government, a very heroic moment which elevated their self-confidence after were being injured for a long time under the Dutch authority.

\footnotetext{
${ }^{73}$ Aqib Suminto, Politik Islam Hindia Belanda, pp. 57-58. He also said, “This ordinance is not useful. No robber or dangerous propagandist ever arrested through this ordinance".
} 


\section{BIBLIOGRAPHY}

\section{Unpublished Archives}

Nota van den Assistant-Resident van Batipoeh en Pariaman betreffende het gebeurde te Padang Pandjang in den nacht van 21 op 22 December 1915, Verbaal De Ministerie van Kolonien 15 Juni 1916 No. 41

Letter from De Ambtenaar voor Inlandsche Zaken De Vries to the Resident of West Sumatra No. 41 (Geheim), Onderwerp-Goeroe-Ordonnantie, Fort de Kock (Bukittinggi), September 5, 1928, in Mailrapport 966x/28

Letter from Hassannoeddin gelar Datoek Singo Mangkoeto to the Governor-General of the Netherlands Indies, Fort de Kock (Bukittinggi), August 19, 1928, in Mailrapport 1001x/28

Letter from on the behalf of Permoesjawaratan Oelama2 Minangkabau to the Governor General of Netherlands Indies, Tweede Kamer, Volksraad, and Adviseur voor Inlandsche Zaken, Fort de Kock, August 19, 1928, in Mailrapport 1001x/28

\section{Published Archives}

Staatsblad van Nederlandsch-Indie 1905 No. 550

Staatsblad van Nederlandsch-Indie 1925 No. 219

\section{Books and Articles}

Abdullah, Taufik. 1971. Schools and Politics: The Kaum Muda Movement in West Sumatra (1927-1933). New York: Cornell Modern Indonesia Project.

Alfian. 1989. Muhammadiyah: The Political Behavior of A Muslim Modernist Organization under Dutch Colonialism. Yogyakarta: Gadjah Mada University Press.

Azra, Azyumardi. 2003. Surau: Pendidikan Islam Tradisional dalam Transisi dan Modernisasi. Jakarta: Logos.

Benda, Harry J. and Ruth T. McVey. 1960. The Communist Uprisings of 1926-1927 in Indonesia: Key Documents. New York: Modern Indonesia Project Southeast Asia Program Departement of Far Eastern Studies Cornell University.

Benda, Harry J. 1980. Bulan Sabit dan Matahari Terbit: Islam Indonesia pada Masa Pendudukan Jepang. Jakarta: Pustaka Jaya.

Brugmans, I. J. 1938. Geschiedenis van het Onderwijs in Nederlandsch-Indie. Groningen and Batavia: J. B. Wolters' Uitgevers-Maatschappij N.V.

Daya, Burhanuddin. 1990. Gerakan Pembaharuan Pemikiran Islam: Kasus Sumatera Thawalib. Yogyakarta: Tiara Wacana.

Djamal, Murni. 2002. DR. H. Abdul Karim Amrullah: Pengaruhnya dalam Gerakan Pembaruan Islam di Minangkabau pada Awal Abad ke-20. Jakarta and Leiden: INIS.

Dobbin, Christine. 1983. Islamic Revivalism in a Changing Peasant Economy: Central Sumatra 1784-1847. London \& Malmo: Curzon Press.

Graves, Elizabeth E. 1971. "The Ever-Victorious Buffalo: How the Minangkabau of Indonesia Solved Their 'Colonial Question'”. PhD Dissertation, University of Wisconsin, 1971

----. 1920. Handleiding Ten Dienste van de Inlandsche Bestuursambtenaren op Java en Madoera No. 37/O. E. Mohammedaansch=Inlandsche Zaken. Batavia: het Departement van Binnenlandsch-Bestuur.

HAMKA. 1967. Ajahku: Riwajat Hidup Dr. H. Abd. Karim Amrullah dan Perdjuangan Kaum Agama di Sumatra. Jakarta: Djajamurni.

Hisyam, Muhammad. 2001. "Caught Between Three Fires: The Javanese Pangulu under the Dutch Colonial Administration 1882-1942." PhD Dissertation, University of Leiden.

Hurgronje, C. Snouck. 1993. Tulisan-tulisan tentang Islam di Hindia Belanda (jajaran pertama): Kumpulan Karangan Snouck Hurgronje VII. Jakarta: INIS.

Kartodirdjo, Sartono. 1996. The Peasant' Revolt of Banten in 1888: Its Conditions, Course and Sequel: A Case Study of Social Movements in Indonesia. 'S-Gravenhage: Martinus Nijhoff.

Noer, Deliar. 1982. Gerakan Modern Islam di Indonesia 1900-1942. Jakarta: LP3ES. 
Noer, Deliar. 1973. The Modernist Muslim Movement in Indonesia 1900-1942. Kuala Lumpur: Oxford University Press.

-----. 1928. Overzicht van de Inlandsche en Maleisisch-Chineesche pers/Bureau voor de Volkslectuur en Aanverwante Aangelegenheden. Afd. Pers Overzicht van de Inlandsche pers. Weltevreden: Bureau voor de

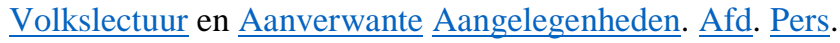

Roff, William R. 1970. "Indonesian and Malay Students in Cairo in the 1920's." INDONESIA Vol. 9.

Schrieke, B. 1955. Indonesian Sociological Studies: Selected Writings of B. Schrieke Part One. The Hague and Bandung: W. van Hoeve Ltd.

Suminto, Aqib. 1985. Politik Islam Hindia Belanda: Het Kantoor voor Inlandsche Zaken. Jakarta: LP3ES.

Zed, Mestika. 2004. Pemberontakan Komunis Silungkang 1927: Studi Gerakan Sosial di Sumatra Barat. Yogyakarta: Syarikat.

Zulqayyim. 2006. Boekittinggi Tempo Doeloe. Padang: Andalas University Press. 